\title{
Gas Chromatography and Mass Spectroscopy (GC-MS) Based Isotopic Abundance Ratio Evaluation of the Biofield Energy Treated Metronidazole
}

ISSN: 2576-9170

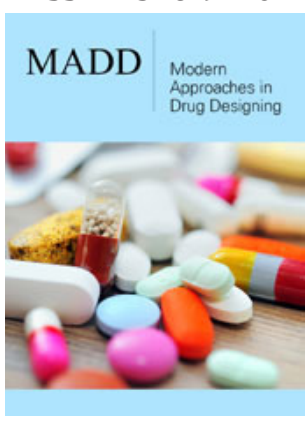

*Corresponding author: Snehasis Jana, Trivedi Science Research Laboratory Pvt. Ltd., Thane (W), Maharashtra, India

Submission: 琒January 27, 2020

Published: 眥 February 18, 2020

Volume 2 - Issue 5

How to cite this article: Gopal Nayak, Mahendra Kumar Trivedi, Alice Branton, Dahryn Trivedi, Snehasis Jana. Gas Chromatography and Mass Spectroscopy (GC-MS) Based Isotopic Abundance Ratio Evaluation of the Biofield Energy Treated Metronidazole. Mod Appro Drug Des.2(5) MADD.000549.2020.

DOI: 10.31031/MADD.2020.02.000549.

Copyright@ Gopal Nayak, This article is distributed under the terms of the Creative Commons Attribution 4.0 International License, which permits unrestricted use and redistribution provided that the original author and source are credited.

\section{Gopal Nayak ${ }^{1 *}$, Mahendra Kumar Trivedi ${ }^{1}$, Alice Branton ${ }^{1}$, Dahryn Trivedi $^{1}$, and Snehasis Jana ${ }^{2}$}

${ }^{1}$ Trivedi Global, Inc., Henderson, USA

${ }^{2}$ Trivedi Science Research Laboratory Pvt. Ltd., India

\begin{abstract}
Metronidazole is a common antimicrobial antibiotic, which is used in the treatment of bacterial vaginosis, giardiasis, trichomoniasis, pseudomembranous colitis, etc. This study was performed to evaluate the impact of the Trivedi Effect ${ }^{\circledR}$ on the structural properties, and the isotopic abundance ratio of metronidazole evaluated using GC-MS analytical techniques. The metronidazole sample was divided into control and treated parts. Only the treated part received the Consciousness Energy Healing Treatment remotely by a well-known Biofield Energy Healer, Gopal Nayak. The GC-MS spectra of both the samples of metronidazole at the retention time 16.4 minutes exhibited the molecular ion peak at $m / z 171[\mathrm{M}]^{+}$ (calculated for $\mathrm{C}_{6} \mathrm{H}_{9} \mathrm{~N}_{3} \mathrm{O}_{3}{ }^{+}, 171.06$ ). The peak area of the Biofield Energy Treated metronidazole was significantly increased by $166.83 \%$ compared to the control sample. The isotopic abundance ratio of $\mathrm{P}_{\mathrm{M}+1} / \mathrm{P}_{\mathrm{M}}$ in the treated metronidazole was significantly decreased by $19.72 \%$ compared with the control sample. Thus, ${ }^{13} \mathrm{C},{ }^{2} \mathrm{H},{ }^{15} \mathrm{~N}$, and ${ }^{17} \mathrm{O}$ contributions from $\left(\mathrm{C}_{6} \mathrm{H}_{9} \mathrm{~N}_{3} \mathrm{O}_{3}\right)^{+}$to $\mathrm{m} / \mathrm{z} 172$ in the treated sample were significantly decreased compared with the control sample. The decreased isotopic composition of the treated metronidazole might be the cause of interference of neutrino via the Trivedi Effect ${ }^{\circledR}$. The isotopic abundance ratios ${ }^{2} \mathrm{H} /{ }^{1} \mathrm{H},{ }^{13} \mathrm{C} /{ }^{12} \mathrm{C},{ }^{17} \mathrm{O} /{ }^{16} \mathrm{O}$, and ${ }^{15} \mathrm{~N} /{ }^{14} \mathrm{~N}$ would highly influence the atomic bond vibration of treated metronidazole. The decreased isotopic abundance ratio would weaken the chemical bond and increase the solubility of the treated metronidazole. The new form of Biofield Energy Treated metronidazole would be very useful to design more efficacious pharmaceutical formulations that might offer a better therapeutic response against bacterial vaginosis, pseudomembranous colitis, trichomoniasis, giardiasis, pelvic inflammatory disease, brain, and respiratory tract infection, etc.
\end{abstract}

Keywords: Metronidazole; Consciousness energy healing treatment; Biofield energy; The Trivedi Effect ${ }^{\circledR}$; GC-MS

\section{Introduction}

Metronidazole is used as an antimicrobial antibiotic. It inhibits the microorganism by means of disturbing the genetic material of the microbial cells [1,2]. It is useful in the treatment of bacterial vaginosis, pseudomembranous colitis, giardiasis, trichomoniasis, pelvic inflammatory disease, brain, oral, and respiratory tract infection, aspiration pneumonia, fungating wounds, rosacea, intra-abdominal infections, periodontitis, lung abscess, amoebiasis, etc. It is also used to treat Giardia in animals [2-6]. The side effects associated to the metronidazole therapy are nausea, vomiting, headache, dizziness, diarrhoea, weight loss, metallic taste in the mouth, abdominal pain, stomatitis, thrombophlebitis, hypersensitivity reactions, CNS toxicity, paraesthesia, etc. [2,7]. Metronidazole delivered in the form of a liquid suspension, tablet, capsule, and intravenous injection [7-9]. It is hazardous to the skin and eye on inhalation and ingestion. It is very slightly soluble in water, chloroform, alcohol, dilute acid, and dimethylformamide $[10,11]$.

The dissolution, absorption, and bioavailability of the pharmaceutical compounds have a direct relation with its physicochemical properties [12]. Worldwide pharmaceutical scientists work on the development of pharmaceuticals. The Trivedi Effect ${ }^{\circledR}$-Consciousness Energy Healing Treatment has a significant impact on the physicochemical properties and bioavailability of pharmaceutical and nutraceutical compounds [13-17]. The Trivedi Effect ${ }^{\circledR}$ is a scientifically proven phenomenon. In which an expert can harness this energy from the 
"Universal Energy Field" and transfer it anywhere on the earth via the possible mediation of neutrinos [18]. The "Biofield" is the electromagnetic energy field generated by the continuous movement of the electrically charged particles (ions, cells, etc.) inside the body. The method of transfer of the Biofield Energy from the healer to the object is called Biofield Energy Healing Treatment, and it has a significant reported positive outcome [19-22]. The National Center of Complementary and Integrative Health has accepted Energy Therapies as a Complementary and Alternative Medicine (CAM) health care approach in addition to other therapies, medicines, i.e., Reiki, yoga, Qi Gong, Tai Chi, Ayurveda, Chinese herb and medicine, hypnotherapy, etc. [23,24]. These CAM therapies have been accepted by most of the U.S.A. people [24]. Similarly, the Trivedi Effect ${ }^{\circledR}$-Consciousness Energy Healing Treatment has also been proved scientifically with outstanding performance in the fields of materials science, chemical science, agricultural science, microbiology, cancer research [25-34], etc. Thus, the Trivedi Effect ${ }^{\circledR}$-Consciousness Energy Healing Treatment could be an economical approach to improve the physicochemical properties of metronidazole. The analysis of stable isotope ratio has various applications in different scientific fields for understanding the isotope effects resulting from the variation of the isotopic composition of the molecule [35,36]. In this study, the isotope ratio analysis can be performed by using the conventional mass spectrometry (MS) techniques, such as gas chromatographymass spectrometry (GC-MS). The GC-MS can detect the isotope composition in low micromolar concentration with sufficient precision [35,37]. Thus, GC-MS based isotopic abundance ratio analysis of $\mathrm{P}_{\mathrm{M}+1} / \mathrm{P}_{\mathrm{M}}\left({ }^{2} \mathrm{H} /{ }^{1} \mathrm{H}\right.$ or ${ }^{13} \mathrm{C} /{ }^{12} \mathrm{C}$ or ${ }^{17} \mathrm{O} /{ }^{16} \mathrm{O}$ or $\left.{ }^{15} \mathrm{~N} /{ }^{14} \mathrm{~N}\right)$ and $\mathrm{P}_{\mathrm{M}+2} / \mathrm{P}_{\mathrm{M}}\left({ }^{18} \mathrm{O} /{ }^{16} \mathrm{O}\right)$ in the metronidazole was evaluated.

\section{Materials and Methods}

\section{Chemicals and reagents}

The test sample metronidazole was purchased from Tokyo Chemical Industry Co., Ltd., Japan, whereas, the other chemicals used in the experiments were purchased in India.

\section{Consciousness energy healing treatment strategies}

The test sample metronidazole powder was divided into two equal parts. One part termed as control and another part as treated samples. The control metronidazole sample did not receive the Biofield Energy Treatment but received treatment from a "sham" healer, who did not have any knowledge about the Biofield Energy Treatment. However, the treated metronidazole was received the Trivedi Effect ${ }^{\circledR}$-Consciousness Energy Healing Treatment remotely for 3 minutes by the renowned Biofield Energy Healer, Gopal Nayak, India. After the treatment, both the samples were kept in sealed conditions and characterized using the GC-MS analytical technique.

\section{Characterization}

Gas Chromatography-Mass Spectrometry (GC-MS) analysis: GCMS of the metronidazole samples were analyzed with the help of Perkin Elmer Gas chromatograph furnished with a PE-5MS (30M x 250 micros x 0.250 microns) capillary column and coupled to a single quadrupole mass detector was operated with electron impact (EI) ionization in positive mode. The oven temperature was programmed from $75{ }^{\circ} \mathrm{C}$ ( 5 min hold) to $280^{\circ} \mathrm{C}$ ( 14 min hold) @ $10{ }^{\circ} \mathrm{C} / \mathrm{min}$ (total run time $40 \mathrm{~min}$ ). The sample was prepared, taking $60 \mathrm{mg}$ of the metronidazole in $3 \mathrm{ml}$ acetonitrile as a diluent. The experimental abundance of each isotope $(\mathrm{C}, \mathrm{O}, \mathrm{H}$, and $\mathrm{N}$ ) can be predicted from the comparison of the height of the isotope peak with respect to the base peak. The values of the natural isotopic abundance of the common elements are obtained from the literature [36,38-40].

The GC-MS based isotopic abundance ratios $\left(\mathrm{P}_{\mathrm{M}+1} / \mathrm{P}_{\mathrm{M}}\right)$ for the control and treated metronidazole was calculated using equation 1.

$\%$ Change in isotopic abundance ratio $=\left[\left(\mathrm{IAR}_{\text {Treated }}-\mathrm{IAR}_{\text {Control }}\right) /\right.$ $\left.\left.\operatorname{IAR}_{\text {Control }}\right)\right]$ x 100 (1)

Where $\mathrm{IAR}_{\text {Treated }}$ and $\mathrm{IAR}_{\text {Control }}=$ isotopic abundance ratio in the treated and control sample.

\section{Results and Discussion}

\section{Gas Chromatography-Mass Spectrometry (GC-MS) analysis}

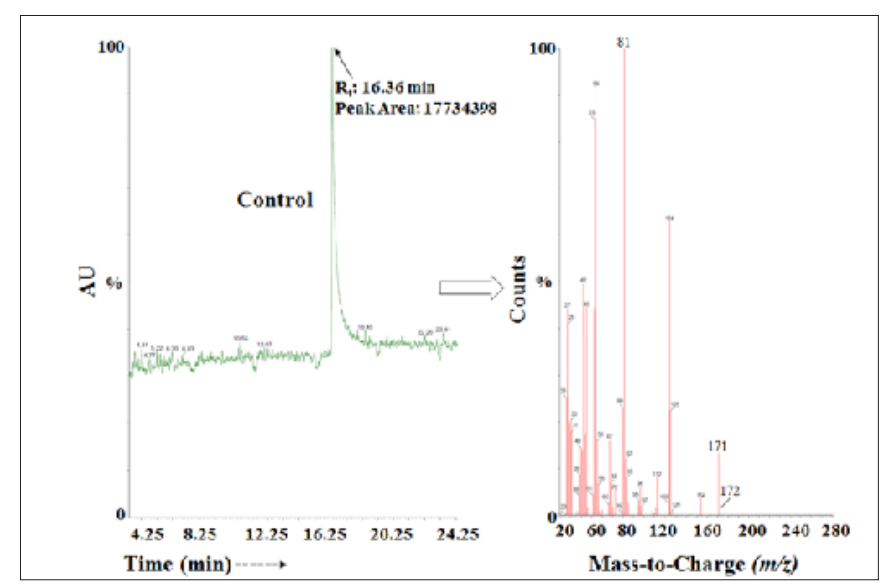

Figure 1: The GC-MS chromatogram and mass spectra of the control metronidazole.

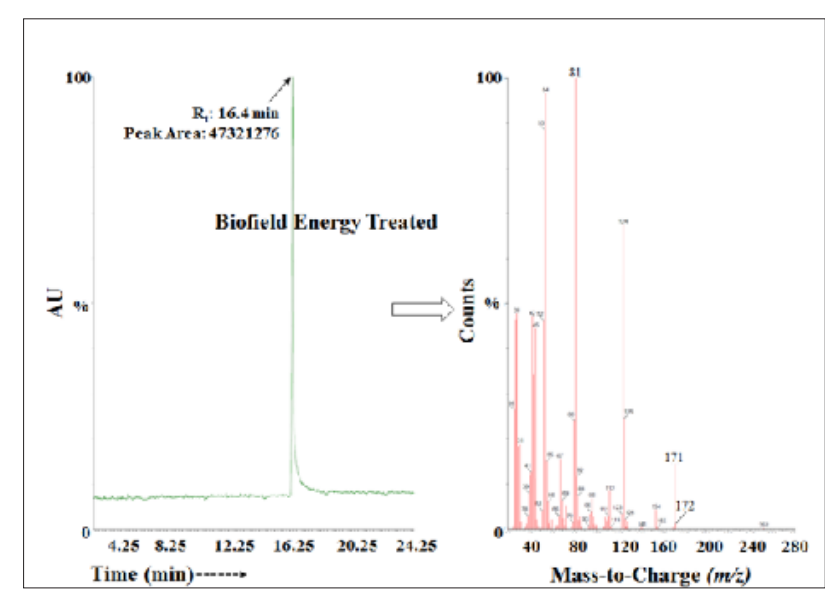

Figure 2: The GC-MS chromatogram and mass spectra of the Biofield energy treated metronidazole. 
The GC chromatograms of both the metronidazole samples showed the presence of a single chromatographic peak (Figure 1 \& 2) at retention time $\left(R_{t}\right)$ of 16.4 minutes. The peak area of the Biofield Energy Treated metronidazole (47321276) was significantly increased by $166.83 \%$ compared to the control sample (17734398). This data indicated that the solubility of the Biofield Energy Treated metronidazole was significantly increased compared to the control sample. The previous study also supported the data and showed that the Biofield Energy Treated metronidazole significantly decreased the crystallite sizes and particle sizes, increased surface area, and thermal stability compared with the control sample [41]. The increased surface area of the treated metronidazole might increase the solubility compared to the control sample, which was supported by the peak area.

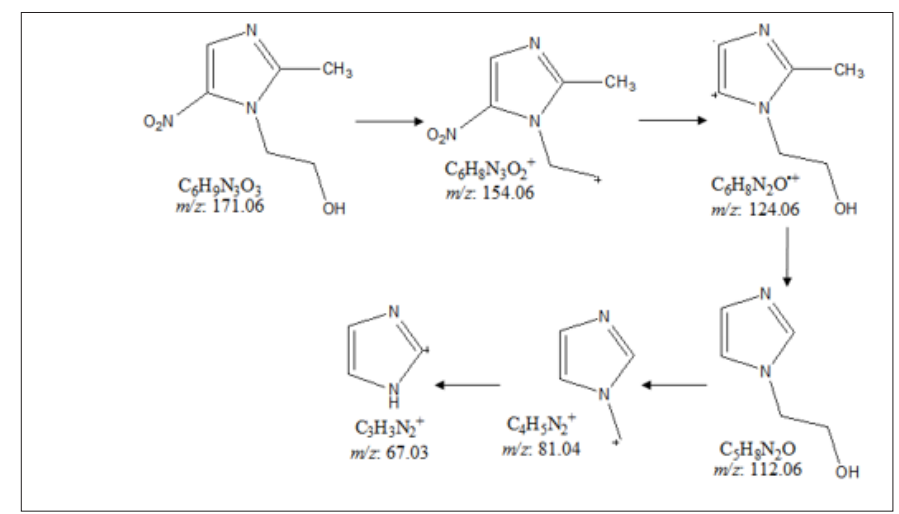

Figure 3: Proposed fragmentation pattern of metronidazole.

Metronidazole shows the molecular mass peak $[\mathrm{M}]^{+}$at $\mathrm{m} / \mathrm{z} 171$ in the spectrum in positive ion mode [42]. The parent molecular peak of metronidazole at $\mathrm{m} / z 171[\mathrm{M}]^{+}$(calculated for $\mathrm{C}_{6} \mathrm{H}_{9} \mathrm{~N}_{3} \mathrm{O}_{3}{ }^{+}$, 171.06) along with the fragment peaks near $m / z 154,124,112$, 81, and 67 were proposed corresponded to the molecular formula $\mathrm{C}_{6} \mathrm{H}_{8} \mathrm{~N}_{3} \mathrm{O}_{2}{ }^{+}, \mathrm{C}_{6} \mathrm{H}_{8} \mathrm{~N}_{2} \mathrm{O}^{+}, \mathrm{C}_{5} \mathrm{H}_{8} \mathrm{~N}_{2} \mathrm{O}, \mathrm{C}_{4} \mathrm{H}_{5} \mathrm{~N}_{2}{ }^{+}$, and $\mathrm{C}_{3} \mathrm{H}_{3} \mathrm{~N}_{2}{ }^{+}$, respectively (Figures 3). The mass peak intensities influence the isotopic abundance ratio.

The GC-MS based theoretical calculation of $\mathrm{P}_{\mathrm{M}+1}$ for metronidazole was presented as below:

$\mathrm{P}\left({ }^{13} \mathrm{C}\right)=\left[(6 \times 1.1 \%) \times 14.44 \%\right.$ (the actual size of the $\mathrm{M}^{+}$peak $\left.)\right]$ $/ 100 \%=0.95 \%$

$$
\begin{aligned}
& P\left({ }^{2} \mathrm{H}\right)=[(9 \times 0.015 \%) \times 14.44 \%] / 100 \%=0.019 \% \\
& P\left({ }^{15} \mathrm{~N}\right)=[(3 \times 0.4 \%) \times 14.44 \%] / 100 \%=0.17 \% \\
& P\left({ }^{17} \mathrm{O}\right)=[(3 \times 0.04 \%) \times 14.44 \%] / 100 \%=0.017 \%
\end{aligned}
$$

$\mathrm{P}_{\mathrm{M}+1}$, i.e. ${ }^{13} \mathrm{C},{ }^{2} \mathrm{H},{ }^{15} \mathrm{~N}$, and ${ }^{17} \mathrm{O}$ contributions from $\left(\mathrm{C}_{6} \mathrm{H}_{9} \mathrm{~N}_{3} \mathrm{O}_{3}\right)^{+}$to $m / z 172=1.16 \%$

From the above calculation, it has been found that ${ }^{13} \mathrm{C}$ and ${ }^{15} \mathrm{~N}$ have major contribution to $\mathrm{m} / \mathrm{z} 172$. The calculated isotopic abundance $(1.16 \%)$ was close to the experimentally observed value (1.08\%). The GC-MS based isotopic abundance ratio was calculated. The $\mathrm{P}_{\mathrm{M}}$ and $\mathrm{P}_{\mathrm{M}+1}$ for metronidazole near $\mathrm{m} / \mathrm{z} 171$ and 172 , respectively were obtained from the observed relative peak intensities of $\left[\mathrm{M}^{+}\right]$and $\left[(\mathrm{M}+1)^{+}\right]$, respectively (Table 1$)$. The isotopic abundance ratio of $\mathrm{P}_{\mathrm{M}+1} / \mathrm{P}_{\mathrm{M}}$ in the Biofield Energy Treated metronidazole was significantly decreased by $19.72 \%$ compared with the control sample (Table 1). Which indicated that the ${ }^{13} \mathrm{C}$, ${ }^{2} \mathrm{H},{ }^{15} \mathrm{~N}$, and ${ }^{17} \mathrm{O}$ contributions from $\left(\mathrm{C}_{6} \mathrm{H}_{9} \mathrm{~N}_{3} \mathrm{O}_{3}\right)^{+}$to $\mathrm{m} / \mathrm{z} 172$ in the Biofield Energy Treated metronidazole were significantly increased compared with the control sample.

Table 1: GC-MS based isotopic abundance analysis results of metronidazole in control and Biofield Energy Treated samples.

\begin{tabular}{|c|c|c|}
\hline Parameter & Control Sample & Biofield Energy Treated Sample \\
\hline $\mathrm{P}_{\mathrm{M}}$ at $m / \mathrm{z} 171(\%)$ & 14.44 & 14.49 \\
\hline $\mathrm{P}_{\mathrm{M}}+1$ at $m / \mathrm{z} 172(\%)$ & 1.08 & 0.87 \\
\hline $\mathrm{P}_{\mathrm{M}}+1 / \mathrm{P}_{\mathrm{M}}$ & 0.07 & 0.06 \\
\hline \% Change of isotopic abundance ratio $\left(\mathrm{P}_{\mathrm{M}+1} / \mathrm{P}_{\mathrm{M}}\right)$ with respect to the control sample & -19.72 \\
\hline
\end{tabular}

$\mathrm{P}_{\mathrm{M}}$ : The relative peak intensity of the parent molecular ion $\left[\mathrm{M}^{+}\right] ; \mathrm{P}_{\mathrm{M}+1}$ : the relative peak intensity of the isotopic molecular ion $\left[(\mathrm{M}+1)^{+}\right]$; $\mathrm{M}$ : mass of the parent molecule.

The isotopic abundance ratio of $\mathrm{P}_{\mathrm{M}+1} / \mathrm{P}_{\mathrm{M}}\left({ }^{2} \mathrm{H} /{ }^{1} \mathrm{H}\right.$ or ${ }^{13} \mathrm{C} /{ }^{12} \mathrm{C}$ or ${ }^{15} \mathrm{~N} /{ }^{14} \mathrm{~N}$ or ${ }^{17} \mathrm{O} /{ }^{16} \mathrm{O}$ ) in the Biofield Energy Treated metronidazole was significantly decreased compared to the control sample. The natural abundance and relative proportion of the stable isotopes significantly affected by the environment, climate, etc. [43]. The decreased isotopic composition in the molecular level of the Consciousness Energy Healing Treated metronidazole might be due to the alteration in neutron to proton ratio in the nucleus possibly, through the interference of neutrino particles via the Trivedi
Effect $^{\circledR}$. The neutrinos have the ability to interact with protons and neutrons in the nucleus, which indicated a close relation between neutrino and the isotope formation [18,36,37]. The isotopic abundance ratios ${ }^{2} \mathrm{H} /{ }^{1} \mathrm{H},{ }^{13} \mathrm{C} /{ }^{12} \mathrm{C},{ }^{17} \mathrm{O} /{ }^{16} \mathrm{O}$, and ${ }^{15} \mathrm{~N} /{ }^{14} \mathrm{~N}$ would highly influence the atomic bond vibration of treated metronidazole. The decreased isotopic abundance ratio of the Consciousness Energy Healing Treated metronidazole would weaken the chemical bond and increase the solubility in the body. The new form of Biofield Energy Treated metronidazole would be very useful to design more 
efficacious pharmaceutical formulations that might offer better therapeutic response against bacterial and protozoal infection in the vagina, stomach, joints, liver, skin, brain, and respiratory tract; also more effective against aspiration pneumonia, intra-abdominal infections, lung abscess, rosacea, fungating wounds, amoebiasis, oral infections, periodontitis, etc.

\section{Conclusion}

The Trivedi Effect ${ }^{\circledR}$-Consciousness Energy Healing Treatment showed a significant impact on the isotopic abundance ratios of metronidazole. The GC-MS spectra of both the samples of metronidazole at the retention time 16.4 minutes exhibited the molecular ion peak at $m / z 171[\mathrm{M}]^{+}$. The peak area of the Biofield Energy Treated metronidazole was significantly increased by $166.83 \%$ compared to the control sample. The isotopic abundance ratio of $\mathrm{P}_{\mathrm{M}+1} / \mathrm{P}_{\mathrm{M}}$ in the treated metronidazole was significantly decreased by $19.72 \%$ compared with the control sample. Thus, ${ }^{13} \mathrm{C}$, ${ }^{2} \mathrm{H},{ }^{15} \mathrm{~N}$, and ${ }^{17} \mathrm{O}$ contributions from $\left(\mathrm{C}_{6} \mathrm{H}_{9} \mathrm{~N}_{3} \mathrm{O}_{3}\right){ }^{+}$to $\mathrm{m} / \mathrm{z} 172$ in the treated sample were significantly decreased compared with the control sample. The decreased isotopic composition of the treated metronidazole might be the cause of interference of neutrino via the Trivedi Effect ${ }^{\circledR}$. The isotopic abundance ratios ${ }^{2} \mathrm{H} /{ }^{1} \mathrm{H}$, ${ }^{13} \mathrm{C} /{ }^{12} \mathrm{C},{ }^{17} \mathrm{O} /{ }^{16} \mathrm{O}$, and ${ }^{15} \mathrm{~N} /{ }^{14} \mathrm{~N}$ would highly influence the atomic bond vibration of treated metronidazole. The decreased isotopic abundance ratio would weaken the chemical bond and increase the solubility of the treated metronidazole. The new form of Biofield Energy Treated metronidazole would be very useful to design more efficacious pharmaceutical formulations that might offer better therapeutic response against bacterial and protozoal infection in the vagina, stomach, joints, liver, skin, brain, and respiratory tract; also more effective against aspiration pneumonia, intra-abdominal infections, lung abscess, rosacea, fungating wounds, amoebiasis, oral infections, periodontitis, etc.

\section{Acknowledgement}

The authors are grateful to Sophisticated Instrumentation Centre for Applied Research \& Testing (SICART) India, Trivedi Science, Trivedi Global, Inc., and Trivedi Master Wellness for their assistance and support during this work.

\section{References}

1. Metronidazole (2019) The American society of health-system pharmacists.

2. Freeman CD, Klutman NE, Lamp KC (1997) Metronidazole. A therapeutic review and update. Drugs 54(5): 679-708.

3. Joesoef MR, Schmid GP, Hillier SL (1999) Bacterial vaginosis: Review of treatment options and potential clinical indications for therapy. Clin Infect Dis 1: S57-65.

4. Shennan A, Crawshaw S, Briley A, Hawken J, Seed P, et al. (2006) A randomised controlled trial of metronidazole for the prevention of preterm birth in women positive for cervicovaginal fetal fibronectin: The premet study. BJOG 113(1): 65-74.

5. Zar FA, Bakkanagari SR, Moorthi KM, Davis MB (2007) A comparison of vancomycin and metronidazole for the treatment of Clostridium difficile-associated diarrhea, stratified by disease severity. Clin Infect Dis 45(3): 302-307.

6. Barr SC, Bowman DD, Heller RL (1994) Efficacy of fenbendazole against giardiasis in dogs. Am J Vet Res 55(7): 988-990.

7. Asnaashari S, Khoei NS, Zarrintan MH, Adibkia K, Javadzadeh Y (2011) Preparation and evaluation of novel metronidazole sustained release and floating matrix tablets. Pharm Dev Technol 16(4): 400-407.

8. Kling PA, Burman LG (1989) Serum and tissue pharmacokinetics of intravenous metronidazole in surgical patients. Acta Chir Scand 155(67): 347-350.

9. Bohbot JM, Vicaut E, Fagnen D, Brauman M (2010) Treatment of bacterial vaginosis: A multicenter, double-blind, double dummy, randomised phase III study comparing secnidazole and metronidazole. Infectious Diseases in Obstetrics and Gynecology.

10. http://www.sciencelab.com/msds.php?msdsId=9925551

11.h t tp s://pubchem.ncbi.nlm.nih.gov/compound/ metronidazole\#section=Solubility

12. Chereson R (2009) Bioavailability, bioequivalence, and drug selection. In: Makoid CM, Vuchetich PJ, Banakar UV (Eds.), Basic pharmacokinetics ( $1^{\text {st }}$ edn), Pharmaceutical Press, London, UK.

13. Branton A, Trivedi MK, Trivedi D, Nayak G (2018) Evaluation of the physicochemical and thermal properties of the biofield energy healing treated ofloxacin. J Pharm Pharmaceutics 5: 80-87.

14. Nayak G, Trivedi MK, Branton A, Trivedi D, Jana S (2018) Evaluation of the consciousness energy healing treated berberine chloride using PXRD, PSA, and DSC Analysis. Food Sci Nutr Technol 3(6): 000168.

15. Trivedi D, Trivedi MK, Branton A, Nayak G, Jana S (2018) Evaluation of consciousness energy healing treated pyridoxine (vitamin B6). Global Journal of Medical Research: (L) Nutrition \& Food Science 18(1): 15-23.

16. Branton A, Jana S (2017) The influence of energy of consciousness healing treatment on low bioavailable resveratrol in male Sprague Dawley rats. International Journal of Clinical and Developmental Anatomy 3(3): 9-15.

17. Branton A, Jana S (2017) The use of novel and unique biofield energy healing treatment for the improvement of poorly bioavailable compound, berberine in male Sprague Dawley rats. American Journal of Clinical and Experimental Medicine 5(4): 138-144.

18. Trivedi MK, Mohan TRR (2016) Biofield energy signals, energy transmission and neutrinos. American Journal of Modern Physics 5(6): 172-176.

19. Rubik B (2002) The biofield hypothesis: Its biophysical basis and role in medicine. J Altern Complement Med 8(6): 703-717.

20. Nemeth L (2008) Energy and biofield therapies in practice. Beginnings 28(3): 4-5.

21. Ruiz RM, Cajavilca C, Varon J (2008) Einthoven's string galvanometer: The first electrocardiograph. Tex Heart Inst J 35(2): 174-178.

22. Rubik B, Muehsam D, Hammerschlag R, Jain S (2015) Biofield science and healing: history, terminology, and concepts. Glob Adv Health Med 4: 8-14.

23. Koithan M (2009) Introducing complementary and alternative therapies. J Nurse Pract 5(1): 18-20.

24. Barnes PM, Bloom B, Nahin RL (2008) Complementary and alternative medicine use among adults and children: United States, 2007. Natl Health Stat Report 10(12): 1-23.

25. Trivedi MK, Tallapragada RM (2008) A transcendental to changing metal powder characteristics. Met Powder Rep 63(9): 22-28, 31. 
26. Trivedi MK, Patil S, Tallapragada RM (2013) Effect of biofield treatment on the physical and thermal characteristics of silicon, tin and lead powders. J Material Sci Eng 2(3): 125.

27. Trivedi MK, Branton A, Trivedi D, Nayak G, Panda P, et al. (2016) Isotopic abundance ratio analysis of 1,2,3-trimethoxybenzene (TMB) after biofield energy treatment (the Trivedi Effect ${ }^{\circledR}$ ) using gas chromatography-mass spectrometry. American Journal of Applied Chemistry 4(4): 132-140.

28. Trivedi MK, Branton A, Trivedi D, Nayak G, Sethi KK, et al. (2016) Evaluation of isotopic abundance ratio in biofield energy treated nitrophenol derivatives using gas chromatography-mass spectrometry. American Journal of Chemical Engineering 4(3): 68-77.

29. Trivedi MK, Branton A, Trivedi D, Nayak G, Gangwar M, et al. (2015) Agronomic characteristics, growth analysis, and yield response of biofield treated mustard, cowpea, horse gram, and groundnuts. International Journal of Genetics and Genomics 3(6): 74-80.

30. Trivedi MK, Branton A, Trivedi D, Nayak G, Mondal SC, et al. (2015) Evaluation of plant growth, yield and yield attributes of biofield energy treated mustard (Brassica juncea) and chickpea (Cicer arietinum) seeds. Agriculture, Forestry and Fisheries 4(6): 291-295.

31. Trivedi MK, Branton A, Trivedi D, Nayak G, Mondal SC, et al. (2015) Antimicrobial sensitivity, biochemical characteristics and biotyping of Staphylococcus saprophyticus: An impact of biofield energy treatment. J Women's Health Care 4(6): 271.

32. Trivedi MK, Branton A, Trivedi D, Nayak G, Shettigar H, et al. (2015) Antibiogram of multidrug-resistant isolates of Pseudomonas aeruginosa after biofield treatment. J Infect Dis Ther 3(5): 244.

33. Trivedi MK, Patil S, Shettigar H, Mondal SC, Jana S (2015) The potential impact of biofield treatment on human brain tumor cells: A time-lapse video microscopy. J Integr Oncol 4: 141.
34. Trivedi MK, Patil S, Shettigar H, Gangwar M, Jana S (2015) In vitro evaluation of biofield treatment on cancer biomarkers involved in endometrial and prostate cancer cell lines. J Cancer Sci Ther 7(6): 253257.

35. Schellekens RC, Stellaard F, Woerdenbag HJ, Frijlink HW, Kosterink JG (2011) Applications of stable isotopes in clinical pharmacology. Br J Clin Pharmacol 72(6): 879-897.

36. Weisel CP, Park S, Pyo H, Mohan K, Witz G (2003) Use of stable isotopically labeled benzene to evaluate environmental exposures. J Expo Anal Environ Epidemiol 13(5): 393-402.

37. Muccio Z, Jackson GP (2009) Isotope ratio mass spectrometry. Analyst 134(2): 213-222.

38. Rosman KJR, Taylor PDP (1998) Isotopic compositions of the elements 1997 (Technical Report). Pure Appl Chem 70(1): 217-235.

39. Smith RM (2004) Understanding Mass Spectra: A Basic Approach. $\left(2^{\text {nd }}\right.$ edn), John Wiley \& Sons, Inc, USA.

40. Jürgen H (2004) Gross Mass Spectrometry: A Textbook. (2 $2^{\text {nd }}$ edn), Springer, Berlin, Germany.

41. Nayak G, Trivedi MK, Branton A, Trivedi D, Jana S (2019) Spectroscopic and calorimetric evaluation of the consciousness energy healing treated metronidazole. Curr Res Bioorg Org Chem: 1-9.

42. Pascariu M, Niculescu M, Belengeanu D, Șerb A, Božin L, et al. (2015) Radical cations in EI-MS analysis of drugs. I. Riboflavin, epinephrine, chloramphenicol, metronidazole and dipyridamole. Revista De Chimie 66: 1582-1589.

43. Santesteban LG, Miranda C, Barbarin I, Royo JB (2014) Application of the measurement of the natural abundance of stable isotopes in viticulture: A review. Australian Journal of Grape and Wine Research 21(2): 157167. 